\title{
FACTORS AFFECTING PREVENTION PRACTICES OF DENGUE FEVER WITHIN THE COMMUNITIES IN ACEH PROVINCE, INDONESIA
}

Zubir

Department of Environmental Health, Health Polytechnic of Aceh (Politeknik Kesehatan Kemenkes Aceh), Aceh Province, Indonesia

Corresponding Author:

Zubir

Email: zubirkesling1@gmail.com

\begin{abstract}
Dengue fever is a mosquito-borne disease that occurs in tropical and sub-tropical areas of the world. A severe form of dengue fever, also called dengue haemorrhagic fever, can cause severe bleeding, a sudden drop in blood pressure (shock) and death. The incidence of dengue fever has grown dramatically around the world in recent decades. The purpose of this study was to determine factors affecting prevention practices for dengue fever within the community. A cross-sectional study was conducted in the the municipality of Banda Aceh and district of Aceh Besar, Aceh Province, Indonesia. The sample size was 203, and the study instrument was a questionnaire. The study results showed that female respondents, 71 (75,5\%) seem to have practiced prevention of dengue fever more as compared to the males $(58,7 \%)$ or 64 respondents. Respondents in early adulthood ( 75 people or $54.7 \%$ ) practiced more dengue prevention than older respondents. Meanwhile, respondents with higher levels of education, 85 (87.6\%) practiced more dengue prevention than respondents with a middle level of education (47.2\%) or 50 respondents. Respondents with good knowledge about dengue fever 128 (74\%) practiced more prevention of dengue fever than respondent with a poor knowledge (23.3\%) or 7 respondents. Respondents who had a positive attitude to the prevention of dengue fever, 108 (85.7\%) practiced much more prevention than respondents who had a negative attitude (33.3\%) or 25 respondents. Factors most affecting prevention practices for dengue fever were knowledge, attitude, education level, age and gender. Health promotion related to prevention of dengue fever should be done more in the media, especially using televison.
\end{abstract}

Keywords: factors affecting, prevention practices, dengue fever

\section{INTRODUCTION}

Dengue fever is a mosquito-borne disease that occurs in tropical and sub-tropical areas of the world. ${ }^{1}$ Dengue is transmitted by the bite of a mosquito infected with one of the four dengue virus serotypes. It is a febrile illness that affects infants, young children and adults with symptoms appearing 3-14 days after the infected bite. $^{2}$ Dengue is a fast emerging pandemic-prone viral disease in many parts of the world. Dengue flourishes in poor urban areas, suburbs and the countryside but also affects more affluent neighborhoods in tropical and sub-tropical countries. $^{3}$

Dengue is transmitted between people by the mosquitoes Aedes aegypti and Aedes albopictus, which are found throughout the world. Insects that transmit disease are vectors. Symptoms of infection usually begin $4-7$ days after the mosquito bite and typically last 3 - 10 days. In order for transmission to occur the mosquito must feed on a person during a 5- day period when large amounts of virus are in the blood; this period usually begins a little before the person becomes symptomatic. ${ }^{4}$

Some people never have significant symptoms but can still infect mosquitoes. After entering the mosquito in the blood meal, the virus will require an additional 8-12 days incubation before it can then be transmitted to another human. The mosquito remains infected for the remainder of its life, which might be days or a few weeks. In rare cases, dengue can be transmitted through organ transplants or blood transfusions from infected donors, and there is evidence of transmission from an infected pregnant mother to her fetus. But in the vast majority of infections, a mosquito bite is normally responsible. ${ }^{4}$

Dengue fever's most common signs and symptoms include: fever, as high as $106^{\circ} \mathrm{F}\left(41^{\circ} \mathrm{C}\right)$, headaches, muscle, bone and joint pain and pain behind the eyes. The signs and symptoms may also include a widespread rash, nausea and vomiting. Rarely, minor bleeding from the gums or the nose. ${ }^{5}$ Most patients recover within a week or so. In some cases, symptoms worsen and can become life-threatening. Blood vessels often become damaged and leaky, and the number of clotforming cells (platelets) in the patient's bloodstream drops. This can cause: bleeding from the nose and the mouth, severe abdominal pain, persistent vomiting, bleeding under the skin, which might look like bruising and there may also be problems with the lungs, the liver and the heart. ${ }^{5}$ 
The incidence of dengue has grown dramatically around the world in recent decades. The actual numbers of dengue cases are under-reported and many cases are mis-classified. One recent estimate indicates 390 million dengue infections per year (95\% credible interval $284-528$ million), of which 96 million (67-136 million) manifested clinically (with any severity of disease). ${ }^{6}$ Another study, of the prevalence of dengue, estimates that 3.9 billion people, in 128 countries, are at risk of infection with dengue viruses. ${ }^{7}$ Although millions of cases of dengue infection occur worldwide each year, the dengue fever is most common in Southeast Asia and the islands of the Western Pacific (Melanesia), it has also been increasing rapidly in Latin America and the Caribbean. ${ }^{1}$

One of the countries in Southeast Asia that has the higher incidence of dengue is Indonesia. The incidence rate of dengue in Indonesia in 2014 was $75 / 100,000$ population, which increased to $89 / 100,000$ population in 2015. Aceh Province had one of the highest of the incident rate of dengue fever in Indonesia. ${ }^{8}$ According to the data from the Indonesia Ministry of Health, in 2015 the incident rate of dengue fever in Aceh Province was $142.2 / 100,000$ population and it was the seventh highest amongst the 34 provinces in Indonesia. ${ }^{8}$

Aceh province consists of 23 districts/municipalities, and two of them were the locations of this study, i.e Municipality of Banda Aceh and District of Aceh Besar. The number of cases dengue fever in Banda Aceh in 2015 was 127 cases hospitalized, ${ }^{9}$ including 1 case of death. Meanwhile, in Aceh Besar in 2015 was 78 cases hospitalized. ${ }^{10}$

In Aceh province, usually if someone has a fever for a few days and the family thinks that it could be due to dengue fever, they will take the patient to the community health entre (Puskesmas) or others health facility for treatment. Wealthy people may however go to their local doctor in the private practice. Meanwhile, whenever there is an outbreak of dengue fever, the local government will prepare all the government health facilities (community health centres and hospitals) to be ready to treat dengue patients and also will increase the health promotion in the community related to early detection of dengue fever through various media and government or community facilities such as mosques, churches, public offices, etc. Usually when there is an outbreak, tens to hundreds of patients will be hospitalized within a month in each district/municipality.

Many efforts to prevent dengue fever have been conducted by Indonesia government and local government; in particular to increase the potential for community participation in the eradication of mosquito breeding sites. The government routinely and continuously provides counseling to the community for the prevention of dengue fever. Actions that should be taken by communities for preventing dengue fever include cleaning up rubbish that could contain water where mosquitos could breed like discarded containers and old tyres, close off all water tanks and reservoirs, recycle goods that have the potential to contain water where mosquito larvae could thrive, sprinkle lavacide powder onto the surface of water tanks or reservoirs that are difficult to close-off, clean up drains that have stagnant water in them, use mosquito repellent on the skin and use mosquito bed nets for sleeping, have good lighting and ventilation in the home, do not hang clothes inside the house, etc. ${ }^{14}$ The purpose of this study was to determine the factors affecting prevention practices for dengue fever within the community in municipality of Banda Aceh and district of Aceh Besar, Aceh Province, Indonesia.

\section{METHODOLOGY}

\section{Study Location}

This study was conducted in the municipality of Banda Aceh and district of Aceh Besar, Aceh Province, Indonesia. These areas are two of the 23 districts/municipalities in Aceh Province. Banda Aceh has 9 sub-districts with a total population in 2014 of 267,340 , and is also the capital city of Aceh Province. ${ }^{11}$ Meanwhile, Aceh Besar, which surrounds Banda Aceh has 23 sub-districts with a total population in 2014 of $384.618 .{ }^{12}$

\section{Study Design and Population}

This was a descriptive study design with the crosssectional method. The population for the study was the population living in the municipality of Banda Aceh or district of Aceh Besar in 2016. The minimum necessary sample size for this study calculated using the Lameshow formula ${ }^{13}$ was 213 people. Data collection was done in April and May, 2016.

\section{Inclusion and exclusion criteria}

Inclusion criteria for this study were minimal education as a high school graduate or equivalent and aged from 18 to 60 years old. Meanwhile, the exclusion criteria was less than one-year residence in the municipality of Banda Aceh or district of Aceh Besar.

\section{Variables}

This study had one dependent variable that was prevention practices (the actions that were taken by the respondents to prevent catching dengue fever in their home or environment) and 5 independent variables viz: gender, age, level of education, knowledge and attitude towards prevention of dengue fever.

\section{Study Instrument \& Data Analysis}

A questionnaire was the main instrument for the data collection in this study. The questionnaire was divided into 4 main parts, viz: a) Identity of 
respondent; with 8 questions, b) Knowledge regarding dengue fever; with 15 questions, c) Attitude towards prevention of dengue fever with 10 questions and d) Dengue fever prevention practices at home with 10 questions. Chi squared was used for bivariate analysis and multiple logistic regression were then used for multivariate analysis

\section{RESULTS}

There were four variables in the characteristics of the respondents, those were: gender, age, education level and occupation. Categorical data were used to represent the characteristics of the respondents. Table 1 sets out the distribution of the variables. In the gender variable, the majority of the respondents were male, 109 (53.7\%) and 94 were females $(46.3 \%)$. The age variable was divided into three groups, viz: $\leq 19$ years old, 20 39 years old and 49-64 years old. Most of the

\section{Table 1: Characteristic of respondents}

respondent, $130(64 \%)$ aged between 20 -39 years old. $52(25.6 \%)$ of the respondents aged between 49-64 years old and $21(10.3 \%)$ were $\leq 19$ years old.

For the level of education variable, half of the respondents were high school graduates(including university students who were still studying), there were 106 of those (52.2\%). The numbers and percentages for the other categories were: bachelor degrees, 50 respondents (24.6\%); diploma graduates 39 respondents $(19.2 \%)$ and masters level were 8 respondents or $3.9 \%$ there were no doctoral or $\mathrm{Ph} \mathrm{D}$ respondents. For the occupation variable $69(34 \%)$ of the respondents were government employees, 66 (32.5\%) were university students, $30(14.8 \%)$ were private company employees, 18 (8.9\%) were housewifes, $11(5.4 \%)$ were temporary workers, $5(2.5 \%)$ were independent business-men and there were 4 or $2 \%$ farmers or fishermen.

\begin{tabular}{lcc}
\hline Variables & Frequency & Percentage \\
\hline Gender & & \\
Female & 94 & 46.3 \\
Male & 109 & 53.7 \\
Total & 203 & 100.0 \\
Age & & \\
$\leq 19$ years old & 21 & 10.3 \\
20- 39 years old & 130 & 64.0 \\
49-64 years old & 52 & 25.6 \\
Total & 203 & 100.0 \\
Education level & & \\
I High school & 106 & 52.2 \\
Diploma & 39 & 19.2 \\
Degree & 50 & 24.6 \\
Master & 8 & 3.9 \\
Doctoral & 0 & 0.0 \\
Total & 203 & 100.0 \\
Occupation & & \\
Housewife & 18 & 8.9 \\
University student & 66 & 32.5 \\
Temporary worker & 11 & 5.4 \\
Farmer/ Fisherman & 4 & 2.0 \\
Private company employed & 30 & 14.8 \\
Government employed & 69 & 34.0 \\
Businessman & 5 & 5.0 \\
Total & 203 & 100.0 \\
\hline
\end{tabular}

As illustrated in Table 3, there were five factors that were found to have a significant relationship with prevention practices for dengue fever; namely gender, age, educational level, knowledge and attitude. Female respondents, 71 $(75,5 \%)$ practice prevention of dengue fever more than the males $(58,7 \%)$ or 64 respondents. Respondents in early adulthood 75 (54.7\%) practiced more dengue prevention than older respondents. Meanwhile, respondents with higher levels of education, $85(87.6 \%)$ practiced dengue prevention more than respondents with middle level education (47.2\%) or 50 respondents. Respondents with good knowledge about dengue fever, 128 (74\%) practiced more prevention of dengue fever compared with respondents with a poor knowledge $(23.3 \%)$ or 7 respondents. Respondents with a positive attitude to the prevention of dengue fever, $108(85.7 \%)$ practiced prevention more than respondents who had a negative attitude $(33.3 \%)$ or 25 respondents. 
Table 2: Chi-Square between Prevention practices for dengue fever and factors studied

\begin{tabular}{|c|c|c|c|c|c|c|c|c|}
\hline \multirow[t]{3}{*}{ Variables } & \multicolumn{4}{|c|}{ Prevention practice } & \multirow{2}{*}{\multicolumn{2}{|c|}{ Totals }} & \multirow[t]{3}{*}{$\mathrm{X}^{2}$} & \multirow[t]{3}{*}{$P$ value } \\
\hline & \multicolumn{2}{|c|}{ Not practiced } & \multicolumn{2}{|c|}{ Practiced } & & & & \\
\hline & No. & $\%$ & No & $\%$ & no & $\%$ & & \\
\hline \multicolumn{9}{|l|}{ Gender } \\
\hline - Female & 23 & 24. & 71 & 75.5 & 94 & 100.0 & 5.67 & $.017^{*}$ \\
\hline - Male & 45 & 41.3 & 64 & 58.7 & 109 & 100.0 & & \\
\hline \multicolumn{9}{|l|}{ Age } \\
\hline -Early adulthood (18- 39 Years ) & 62 & 45.3 & 75 & 54.7 & 137 & 100.0 & 24.55 & $.000^{*}$ \\
\hline -Adult ( $\geq 40$ years old) & 6 & 9.1 & 60 & 90.9 & 66 & 100.0 & & \\
\hline \multicolumn{9}{|l|}{ Education level } \\
\hline -Middle education (= High school) & 56 & 52.8 & 50 & 47.2 & 106 & 100.0 & 35.42 & \\
\hline $\begin{array}{l}\text {-Higher } \\
\text { Masters) }\end{array}$ & \multicolumn{7}{|c|}{ 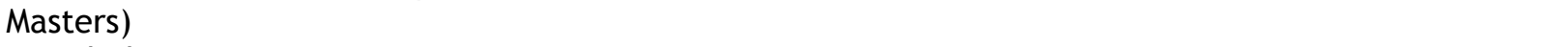 } & $.000^{*}$ \\
\hline \multicolumn{9}{|l|}{ Knowledge } \\
\hline - Poor (score 0-7) & 23 & 76.7 & 7 & 23.3 & 30 & 100.0 & 27.21 & $.000^{*}$ \\
\hline - Good (score (8-15) & 45 & 26.0 & 128 & 74.0 & 173 & 100.0 & & \\
\hline \multicolumn{9}{|l|}{ Attitude } \\
\hline -Negative & 50 & 66.7 & 25 & 33.3 & 75 & 100.0 & 55.30 & $.000^{*}$ \\
\hline -Positive & 18 & 14.3 & 108 & 85.7 & 126 & 100.0 & & \\
\hline
\end{tabular}

Note: * $p<0.05$ was significant

Factors affecting prevention practice of dengue fever, analyzed by multiple logistic regressions with enter method. In the simple logistic regression, the results showed that all the 5 variables above had a $p$ value $<0.05$, then all those variables were entered for further analysis. The result of multiple logistic regressions showed that the five variables above, all had a significant association with prevention practices for dengue fever $(p<0.05)$. The strongest variable that related to prevention practices for dengue fever was knowledge. The adjusted odds ratio of knowledge about dengue fever was $21.60(95 \% \mathrm{Cl}$ : 4.98-94.74). This indicated that people who had good knowledge about dengue fever had 21.60 times greater prevention practices than those who had poor knowledge. Table 3 shows the result of the multiple logistic regressions.

Table 3: Multiple logistic regression analysis: factors affecting prevention practices for dengue fever

\begin{tabular}{lcccccccr}
\hline & & & & & & \multicolumn{3}{c}{$95 \%$ C.I.for EXP(B) } \\
Variables & B & S.E. & Wald & df & Sig. & Exp(B) & Lower & Upper \\
\hline Gender & -1.909 & 0.538 & 12.605 & 1 & $0.000^{*}$ & 0.148 & 1.052 & 0.425 \\
Age & 2.117 & 0.652 & 10.530 & 1 & $0.001^{*}$ & 8.303 & 2.312 & 29.816 \\
Education & 2.266 & 0.544 & 17.347 & 1 & $0.000^{*}$ & 9.644 & 3.320 & 28.018 \\
Knowledge & 3.075 & 0.753 & 16.669 & 1 & $0.000^{*}$ & 21.650 & 4.987 & 94.746 \\
Attitude & 2.571 & 0.489 & 27.589 & 1 & $0.000^{*}$ & 13.075 & 5.010 & 34.121 \\
Constant & -3.512 & 0.741 & 22.454 & 1 & $0.000^{*}$ & .030 & & \\
\hline
\end{tabular}

Note: ${ }^{*} p<0.05$ was significant

\section{DISCUSSION}

Community participation is very important for the prevention of dengue fever and for decreasing the number of cases of dengue fever. As one of the countries with a higher rate of prevalence of dengue fever in the world, Indonesia has programs that involve the community in preventing the disease, these include eradication of mosquito breeding. ${ }^{14}$ Community participation needs to be increased, especially in the rainy season and the transition period to the summer season, because the increase in rainfall will increase the number of places where mosquitoes can breed, hence, the number of cases of dengue fever is liable to increase if community prevention measures are not taken. ${ }^{14}$

There are many factors that influence communities to implement prevention practices for dengue fever. The multiple logistic regression analysis showed that gender, age, level of education, knowledge and attitude to dengue all had a significant relationship with prevention practices for dengue fever. In this study, knowledge had the strongest relationship with prevention practices for dengue fever. Respondents with good knowledge about dengue fever practiced more prevention than respondents with poor knowledge. Some previous studies have 
shown similar results to this study, ${ }^{15-21}$ Contrary with this study result, one study done in Jamaica concluded that knowledge was not associated with prevention behaviour. That study found that good knowledge about dengue fever among the residents of Westmoreland did not translate into adoption of preventive measures. 22.23 The definition of knowledge is facts, information, and skills acquired through experience or education; the theoretical or practical understanding of a subject. ${ }^{24}$ In the change behaviour theory of Green, it is mentioned that knowledge is one of the predisposing factors that will make a person do something according to their knowledge ${ }^{25}$ In this study, respondents with good knowledge about dengue fever used more dengue fever prevention practices in their home and surrounding environment than respondents with poor knowledge.

The results from this study also showed that respondents who had a positive attitude for prevention of dengue fever practiced prevention more than respondents who had a negative attitude. This result is similar to some previous studies, 16, 19, 20. In the public health health, attitude is a relatively stable belief or feeling about a concept, person or object. Attitudes can often be inferred by observing behaviours. ${ }^{26}$ In this study, the attitudes assessed with their consent to do prevention practice of dengue fever. The actions of prevention practice in accordance with the dengue preventive procedure in their community.

Furthermore, this study has shown that level of education has a positive association with prevention practices. Respondents, with a higher level of education, practiced more prevention of dengue compared to those with only middle level education. The higher level of education in this study were respondents who had finished their studies to the level of diploma, bachelor or masters degree. University students were included in the middle education level in this study, as they had not yet finished their study in college or university. Similar results were found in some previous studies. ${ }^{20,30,31}$. Higher levels of education result in changes to better behaviour. Someone with a higher level of education will more easily assess new information or knowledge and think about the risks or advantages of that information for application in their life. In this study, respondents with higher levels of education practiced dengue prevention more due to them knowing about the potential benefits of those actions for their life.

This study revealed a correlation between age and prevention practices for dengue fever. Young adult respondents practiced dengue prevention more than the older respondents. These results were similar to previous studies. ${ }^{31-33}$ Early adulthood in this study were respondents aged from 18 to 39 years of age. This study also found that women also practice more prevention of dengue fever than men. This study result was also similar to that from previous studies. 28,31 Prevention practices for dengue fever at home are done more by women, especially by housewifes, than by men. Besides, women are usually more diligent, more patient, more fussy and cleaner than men especially in an Acehnese culture where the women are usually in charge of the house and it's environment.

Appropriately, the results of this study concluded that knowledge was the strongest factor that determined prevention practices for dengue fever. Hence it is expected that the government should increase it's efforts to prevent dengue fever through continuous health promotions till reaching even the remotest areas in Aceh with the various media, so that everyone will learn about the dangers of dengue and how to prevent dengue fever at home and in their village environment.

There was limitation this study, that was budget and geographical. Some of the sub-districts in Aceh Besar are located far from the capital city (1-3 hours by car or boat) and hence needed high costs for collecting data in there hence data collection was only done in mainland sub-districts that were near to the capital city of Banda Aceh.

\section{CONCLUSIONS}

This study reveals that gender, age, level of education, knowledge and attitude about dengue fever were all factors that affected prevention practices for dengue fever in the municipality of Banda Aceh and district of Aceh Besar. The strongest factor that affected the prevention practices for dengue fever was knowledge. More health promotion related to dengue fever prevention practices should be done in the media, especially on Television. Like other Indonesians, most Acehnese watches TV for hours every day, particularly dramas, infotainment and news. If health promotions about the prevention of dengue fever can be displayed during the commercial breaks or even in special health news programs it could be more effective than the distribution of brochures, pamphlets, etc. Also more information should be sent out from the schools.

\section{ACKNOWLEDGEMENTS}

I am grateful to the heads of the Banda Aceh and Aceh Besar district health offices, who both gave permission to conduct this study. This study did not have any financial support.All the work was done and all the expenses were paid for by the researcher.

\section{REFFERENCES}

1. Mayo Clinic.Dengue fever; Diseases and condition dengue fever [homepage on the Internet]. 2016 [cited 2016, Dec 23]. 
Availablefrom:http://www.mayoclinic.org/dis eases-conditions/dengue

fever/basics/definition/con-20032868.

2. World Health Organization (WHO).Dengue. [Homepage on the Internet].2016. [cited 2016 Dec 12]. Available from: http://www.who.int/topics/dengue/en/.

3. World Health Organization (WHO).Dengue control [Homepage on the Internet]. 2016 [cited 2016 Dec 12]. Available from: . http://www.who.int/denguecontrol/en/.

4. Centers for Deseases Control Prevention (CDC). Dengue [Homepage on the Internet].2016 [cited 2016 Dec 14]. Available from: https://www.cdc.gov/dengue/epidemiology/i ndex.html.

5. Mayo Clinic.Dengue; symptom [homepage on the internet]. 2016. [cited 2016, Dec 23]. Available from: http:/ / www.mayoclinic.org/diseasesconditions/dengue-

fever/basics/symptoms/con-20032868.

6. Bhatt S, Gething PW, Brady OJ, Messina JP, Farlow AW, Moyes CL. et.al. The global distribution and burden of dengue. Nature.2013; 496:504-507.

7. Brady OJ, Gething PW, Bhatt S, Messina JP, Brownstein JS, Hoen AG. et al. Refining the global spatial limits of dengue virus transmission by evidence-based consensus. PLoS Negl Trop Dis. 2012;6: e1760.

8. Kementerian Kesehatan Republik Indonesia (Kemenkes RI) Dengue campaign. [cited 2016 Dec 2]. Available from: http://www.komdat.kemkes.go.id/

9. Dinkes Kota Banda Aceh. Profil Kesehatan Kota Banda Aceh Tahun 2015. Banda Aceh. 2016

10. Dinkes Kabupaten Aceh Besar. Profil Kesehatan Kabupaten Aceh Besar Tahun 2015. Kota Jantho. 2016

11. Badan Pusat Statistik (BPS) Banda Aceh. Jumlah Penduduk dan Kepadatan Penduduk Kotamadya Banda Aceh. 2015 [cited 2016 November 30]. Available from: https://bandaacehkota.bps.go.id/linkTable Dinamis/view/id/.

12. Badan Pusat Statistik (BPS) Aceh Besar. Aceh Besar dalam Angka. Kota Jantho. 2015

13. Lameshow S, Hosmer DW, Klar J, Lwanga SK. Adequacy of sampel Size in Health
Study. New York. Jhon Wiley and Son; 1990.

14. Kementerian Kesehatan Republik Indonesia (Kemenkes RI). Kendalikan DBD dengan PSN 3M Plus. [cited 2016 Dec 3]. Available from: http://www.depkes.go.id/article/view/ 16020900002/kendalikan-dbd-denganpsn-3m-plus.html.

15. Chandren JR, Wong LP, Abu BS. Practices of Dengue Fever Prevention and the Associated Factors among the Orang Asli in Peninsular Malaysia. PLOS Neglected Tropical Diseases.2015 August 12; 0003954.

16. Dhimal M, Aryal KK, Dhimal ML, gautam I, Singh SP, Bhusal CL.et al. Knowledge, Attitude And Practice Regarding Dengue Fever Among The Healthy. Plos one.2014; Vol 9 , Issue 7

17. Makornkan S, Saminpanya $P$, Toomsan A, Intachai P, Saengproa P, Marerngsit D. Knowledge, Attitude and Practice of Dengue Fever Prevention Among the Villagers of Moo 1 Baan Klongsai, Nhongyangsuea Subdistrict, Muaklek District, Saraburi Province, Thailand. Catalyst.2015; Vol 12, № 2.

18. Siregar FA, Abdullah MR, Omar J, Sarumpaet SR, Supriyadi T, Makmur T.et al. Asian Network for Scientific Information Social and Environmental Determinants of Dengue Infection Risk in North Sumatera Province, Indonesia. Asian Journal of Epidemiology.2015; 8 (2): 23-35

19. Lontoh RY, Rattu AJM, Kaunang WPJ. Hubungan Antara Pengetahuan Dan Sikap Dengan Tindakan Pencegahan Demam Berdarah Dengue (Dbd) Di Kelurahan Malalayang 2 Lingkungan III. Pharmaconjurnal Ilmiah Farmasi UNSRAT.2016; Vol. 5 No. 1

20. Bakta IM. Hubungan antara pengetahuan dan sikap terhadap perilaku pemberantasan sarang nyamuk (Psn) sebagai pencegahan demam berdarah dengue (DBD) Di Banjar Badung, Desa Melinggih, Wilayah Puskesmas Payangan Tahun 2014 [Thesis for Degree]. Denpasar, Bali; Fakultas Kedokteran Universitas, Udayana ; 2015

21. Ginandra P. Faktor- faktor yang berhubungan dengan pencegahan demam berdarah di Kabupaten Dairi Sumatera Utara [Thesis for Degree]. Medan. Fakultas Kedokteran Universitas Sumatera Utara; 2015

22. Suhaib F, Todd D, Stennet DC, Ehiri J \& Jolly PE. Knowledge, Attitudes and Practices Regarding Dengue Infection In 
Westmoreland, Jamaica. West Indian Med J.2010; 59(2): 139-146

23. Zulaikha U. Hubungan pengetahuan masyarakat terhadap praktik pencegahan demam berdarah dengue pada masyarakat Kelurahan Pamulang Barat [Thesis for Degre]. Jakarta. Fakultas Kedokteran, Universitas Islam Syarif Hidayatullah; 2014

24. English oxford living dictionary [Internet].Oxford. Knowledge [cited 2016 Nov 22]. Available from: https://en.oxforddictionaries.com/definitio $\mathrm{n} /$ knowledge.

25. Green LW, Kreuter MW. Health Program Planning; An Education \& Ecological Approach. New York. Mc Graw- Hill; 2004

26. PHAC-ASPC. Glossary of Term [Homepage on the internet].2016 [cited 2016 Dec 13]. Available from: http://www.phacaspc.gc.ca/php-psp/ccph-cesp/gloseng.php.

27. Nalongsack S, Yoshida $Y$, Morita S, Sosoouphanh K \& Sakamoto J. Knowledge, Attitude and Practice Regarding Dengue Among People in Pakse, Laos. Nagoya J. Med.2009; Sci. 71. $29 \sim 37$

28. Taksande A, Lakhkari B. Knowledge, Attitude and Practice (KAP) Of Dengue Fever In The Ru-Ral Area Of Central India. Shiraz EMedical Journal.2012; Vol. 13, No. 4

29. Ramzan M, Ansar A, Nadeem S.Dengue Epidemics: Knowledge Perhaps Is The Only Key To Success. J Ayub Med Coll Abbottabad. 2015; 27 (2):402-6

30. Sari AM. Hubungan pendidikan formal ibu dengan perilaku pencegahan demam berdarah dengue pada keluarga [Thesis for Degree].Surakarta, Solo; Fakultas Kedokteran, Universitas Sebelas Maret; 2010

31. Gunandra. Faktor- faktor yang mempengaruhi pencegahan demam berdarah di keluarga, pada masyarakat Kota Banda Aceh tahun 2014 [Thesis for Degree]. Lam Ateuk,Aceh Besar: Fakultas Kedokteran Universitas Abulyatama University; 2014

32. Rollnick S, Mason P, Butler C. Health Behaviour Change; A Guide for Practitioners. London. Churchill Livingstone;1999

33. Monintja TCN. Relationship Between Individual Characteristic, Knowledge, Attitude with PSN DBD Behavior of Community In Kelurahan Malalayang I Kecamatan Malalayang City Of Manado. JIKMU. 2015; Vol. 5, No. 2 